\title{
SEED SCULPTURE OF POLISH SPECIES OF THE GENUS PLANTAGO L.
}

\author{
MAŁGORZATA KLIMKO $^{1}$, KRYSTYNA IDZIKOWSKA ${ }^{2}$, \\ MARIOLA TRUCHAN ${ }^{3}$, ANNA KREFT ${ }^{3}$ \\ ${ }^{1}$ Department of Botany, Agricultural University \\ Wojska Polskiego 71 C, 60-625 Poznań, Poland \\ e-mail: klim@owl.au.poznan.pl \\ ${ }^{2}$ Laboratory of Electron Microscopy \\ Adam Mickiewicz University \\ Grunwaldzka 6, 70-780 Poznań, Poland \\ ${ }^{3}$ Department of Botany and Genetics \\ Institute of Biology and Environmental Protection \\ Pomeranian Pedagogical University \\ Arciszewskiego 22 b, 76-200 Słupsk, Poland
}

(Received: May 12, 2003. Accepted: March 2, 2004)

\begin{abstract}
The paper presents results of research on seed sculpture of Plantago major, P. intermedia, P. media, P. coronopus subsp. coronopus, $P$. maritima subsp. maritima, $P$. atrata subsp. carpatica, $P$. lanceolata and $P$. arenaria. Special attention was paid to the sculpture of the external layer of the testa. Observations were made under a light microscope and a scanning electron microscope. The sculpture typical for each species was presented in micrographs. The results indicate that seed sculpture is a very good interspecific identification feature. The study also confirmed that P. maritima should not be assigned to the section Coronopus DC., but to a separate section Maritima Rahn.
\end{abstract}

KEY WORDS: Plantaginaceae, Plantago, seed sculpture, SEM, LM.

\section{INTRODUCTION}

The genus Plantago of the plantain family (Plantaginaceae) includes over 200 species (Clapham et al. 1962), which are found on all continents. They are herbs, or rarely subshrubs, with inconspicuous flowers collected usually in multiflorous spikes or - less often - in inflorescences composed of one or several flowers each. The fruit is usually a capsule that opens with a lid and contains 1-2 or more seeds. In Poland the most common Plantago species are perennial weeds. Some of them are medicinal plants ( $P$. major, $P$. lanceolata, $P$. arenaria, $P$. media $)$ or bee forage plants (P. media).

Most of the Plantago species are ubiquitous and only three taxa are endangered in Poland: the mountain species $P$. atrata subsp. carpatica and two seaside taxa, $P$. coronopus subsp. coronopus and P. maritima subsp. maritima (Piękoś-Mirkowa 2001; Piotrowska 2001a, b; Zając, Zając 2001).

The ubiquitous taxa show a wide scale of adaptations to various habitats, so they are characterized by a marked morphological and systematic variability (subspecies, varieties and forms), often with imprecisely defined features and no clear ecological differences. Moreover, common species often cross with one another, forming interspecific hybrids.

Tacik (1967), Casper (1974) and Meusel et al. (1978) divide Plantago species into 6 sections: Plantago (P. major L., $P$. intermedia L., P. maritima L., $P$. winteri); Lamprosantha Decne ( $P$. media L.); Coronopus DC ( $P$. coronopus L.), Oreades Decne (P. atrata Hoppe); Arnoglottis T. Tacik $(P$. lanceolata L.) and Psyllium (Juss.) Berneoud (P. arenaria Waldst and Kit., Chrtek (2000), only 4 sections. The taxonomic position of $P$. winteri is still unclear and needs to be explained (Tacik 1967; Piotrowska et al. 1997; Rutkowski 1998; Rothmaler et al. 1982). P. winteri is similar to $P$. major in respect of the number of seeds in the capsule, to $P$. intermedia in respect of leaf shape and some other morphological features, and to P. intermedia subsp. leptostachya in respect of capsule shape. Chater, Cartier (1976) and Chrtek (2000) regards $P$. winteri as a subspecies of $P$. major. 
Hitherto, the classification of Plantago species, both in the European and Polish flora, is based on the monograph by Pilger (1937), who made detailed descriptions of their vegetative organs. In the last two decades, intensive studies were carried out on the sections of the genus distinguished by Pilger (1937). The studies were concerned with the structure of trichomes on leaves, scapes and bracts (Andrzejewska-Golec, Świętosławski 1987, 1989a, b) or occurrence of various groups of iridoids - such as catalpol, plantarenaloside and bartsioside - that are important both for pharmacology (Borkowski 1957; Dusinsky, Tyllova 1960; Raszeja, Gill 1973 etc.), and for identification (Świątek et al. 1981, Andrzejewska-Golec, Świątek 1984; Andrzejewska-Golec et al. 1993, Andrzejewska-Golec 1997; Saadi et al. 1990; Handjieva et al. 1991) and phylogenesis (Rahn 1996). Little carpological information is available. Many keys to identification focus on seed shape, colour and dimensions, especially length. More detailed data were provided by Vodák (1956), Rymkiewicz (1979), and Kulpa (1988), Swabrick and Raymond (1970), but still there is a shortage of information on seed sculpture and its taxonomic significance. The published descriptions of sculpture are imprecise and often misleading.

The numbers of Plantago species in the European and Polish flora are difficult to determine because of discrepancies in taxonomic classification, as some taxa can be regar- ded as separate species or varieties or even forms of the same species. In Europe, Chater, Cartier (1976) distinguished 35 European species and many subspecies, Garcke (1972) described 10 species and 9 subspecies, and Meusel et al. (1978) listed 11 species. In Poland, Szafer et al. (1969) and Rutkowski (1998) reported on 8 species, but earlier Tacik (1967) listed 9 species.

The aim of this study was to make detailed observations of seed sculpture under a light microscope and a scanning electron microscope (SEM), and to clarify the relations between the Polish taxa of the genus Plantago, including 5 common and 3 endangered species.

\section{MATERIAL AND METHODS}

Seeds of most Plantago species were collected in the field in lowland populations (Fig. 1). Within each local population of common species, 30 individuals were collected, and their seeds were later extracted. In the case of $P$. coronopus subsp. coronopus and $P$. maritima subsp. maritima, 30 seeds of each species were collected directly in the field. Only seeds of $P$. atrata subsp. carpatica originated from the Experimental Garden of the Institute of Botany at Zakopane and from herbarium material of POZB.

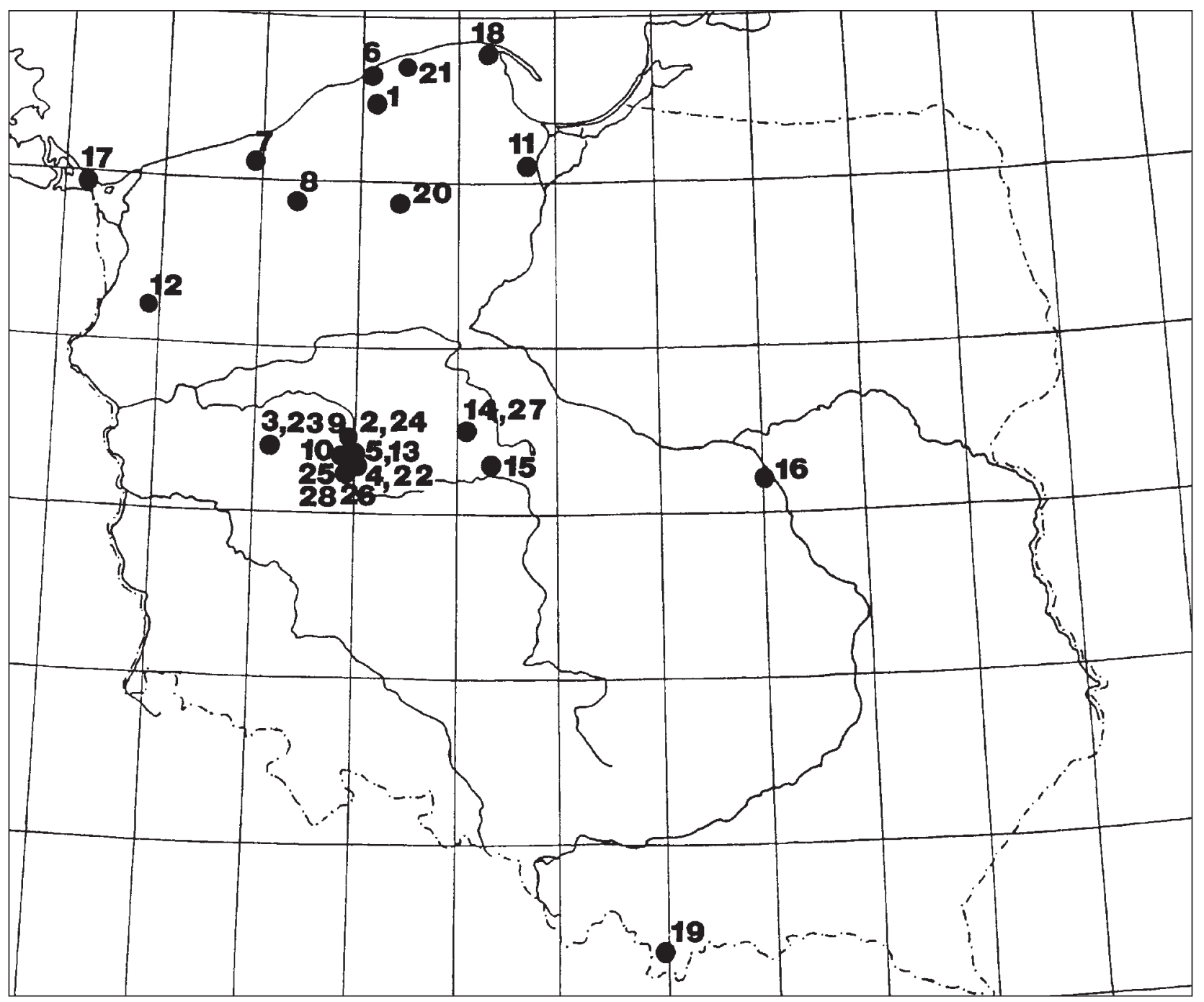

Fig. 1. Distribution of the localities investigated. 
List of localities in particular communes:

\section{P. major}

1. Pomerania, Słupsk Commune - roadsides.

2. Wielkopolska, Poznań Commune - roadsides.

3. Wielkopolska, Nowy Tomyśl Commune - paths.

4. Wielkopolska, Mosina Commune - near buildings.

5. Wielkopolska, Puszczykowo Commune - near buildings.

\section{$P$. intermedia}

6. Pomerania, Rowy, Ustka Commune - edges of lakes.

7. Pomerania, Karlino Commune - cultivated fields.

8. Pomerania, Parsęcko, Szczecinek Commune - cultivated fields.

9. Wielkopolska, Stęszew Commune - edges of lakes.

10. Wielkopolska, Niwka, Puszczykowo Commune - edges of ponds.

\section{P. media}

11. Pomerania, Tczew Commune - slopes of a pond.

12. Pomerania, Pyrzyce Commune - meadow.

13. Wielkopolska, Puszczykowo Commune - roadside ditch.
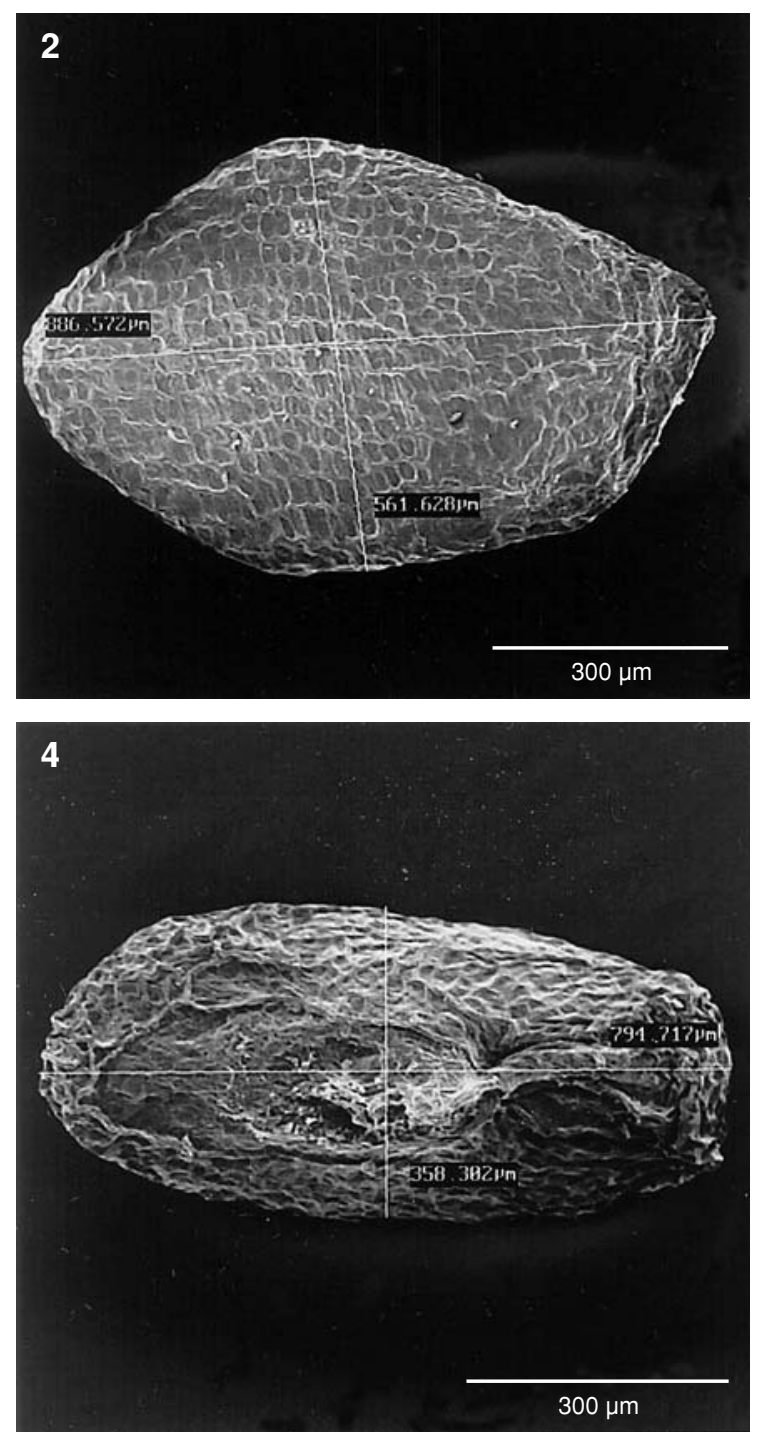

Figs 2-5. Plantago major L. Fig. 2. (SEM) - Seed, dorsal view, (×97). Fig. 3. (SEM) - Seed sculpture on dorsal side, (×312). Fig. 4. (SEM) - Seed, ventral view, $(\times 106)$. Fig. 5. (SEM) - Seed sculpture on ventral side, $(\times 312)$.
14. Wielkopolska, Skorzęcin, Witkowo Commune - meadow.

15. Wielkopolska, Konin Commune - roadside ditch.

16. Mazowsze, Warszawa Commune - slopes of a pond.

P. coronopus subsp. coronopus

17. Pomerania, SE Uznam - Karsibór, Brzeźno Commune - halophilic meadow Croatia, Poradge Commune - roadside.

\section{P. maritima subsp. maritima}

18. Pomerania, Władysławowo Commune - halophilic meadow.

\section{P. atrata subsp. carpatica}

19. Małopolska, Zakopane Commune - Experimental Garden, fresh and herbarium material (POZB), Szalony Wierch.

\section{P. lanceolata}

20. Pomerania, Przechlewo Commune - meadow.

21. Pomerania, Kluki, Smołdzino Commune - meadow.

22. Wielkopolska, Mosina Commune - roadside.

23. Wielkopolska, Nowy Tomyśl Commune - roadside.

24. Wielkopolska, Poznań Commune - roadside.
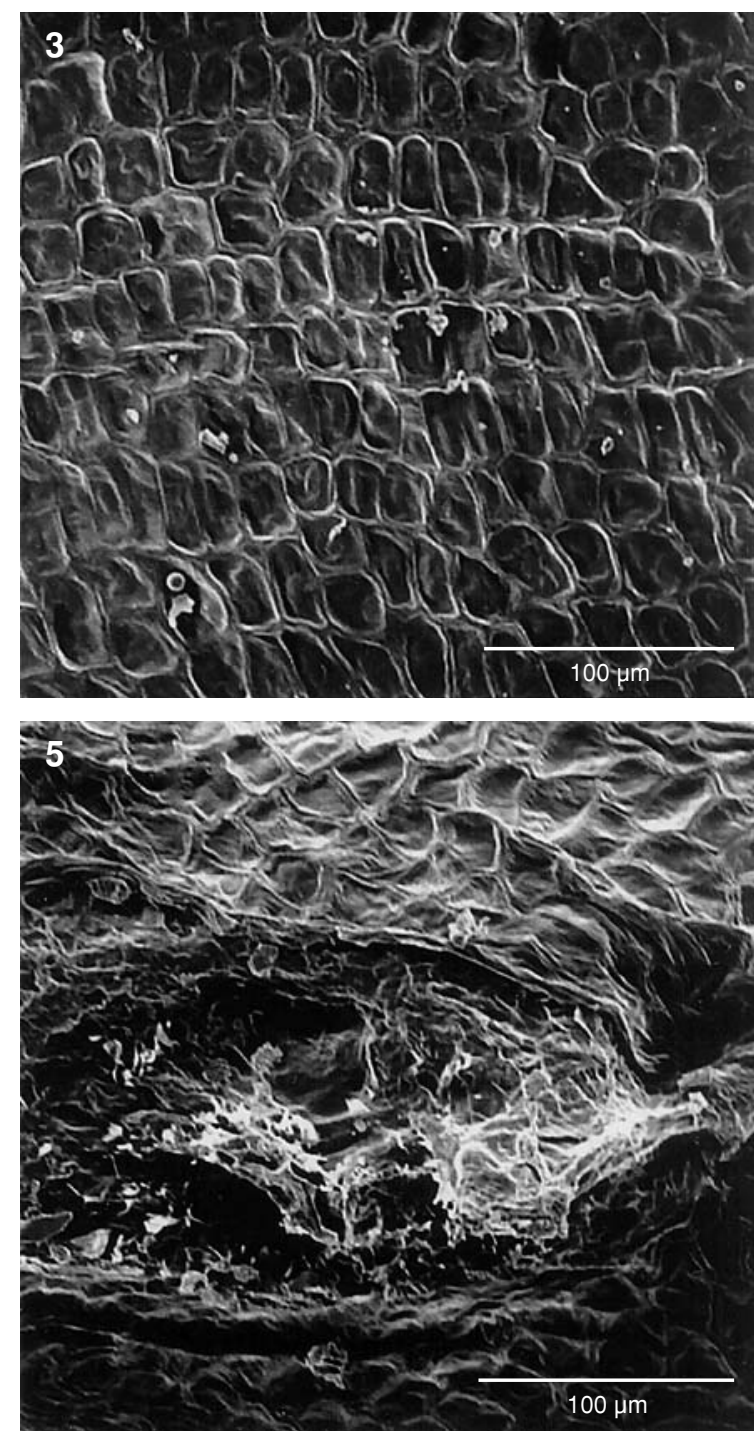

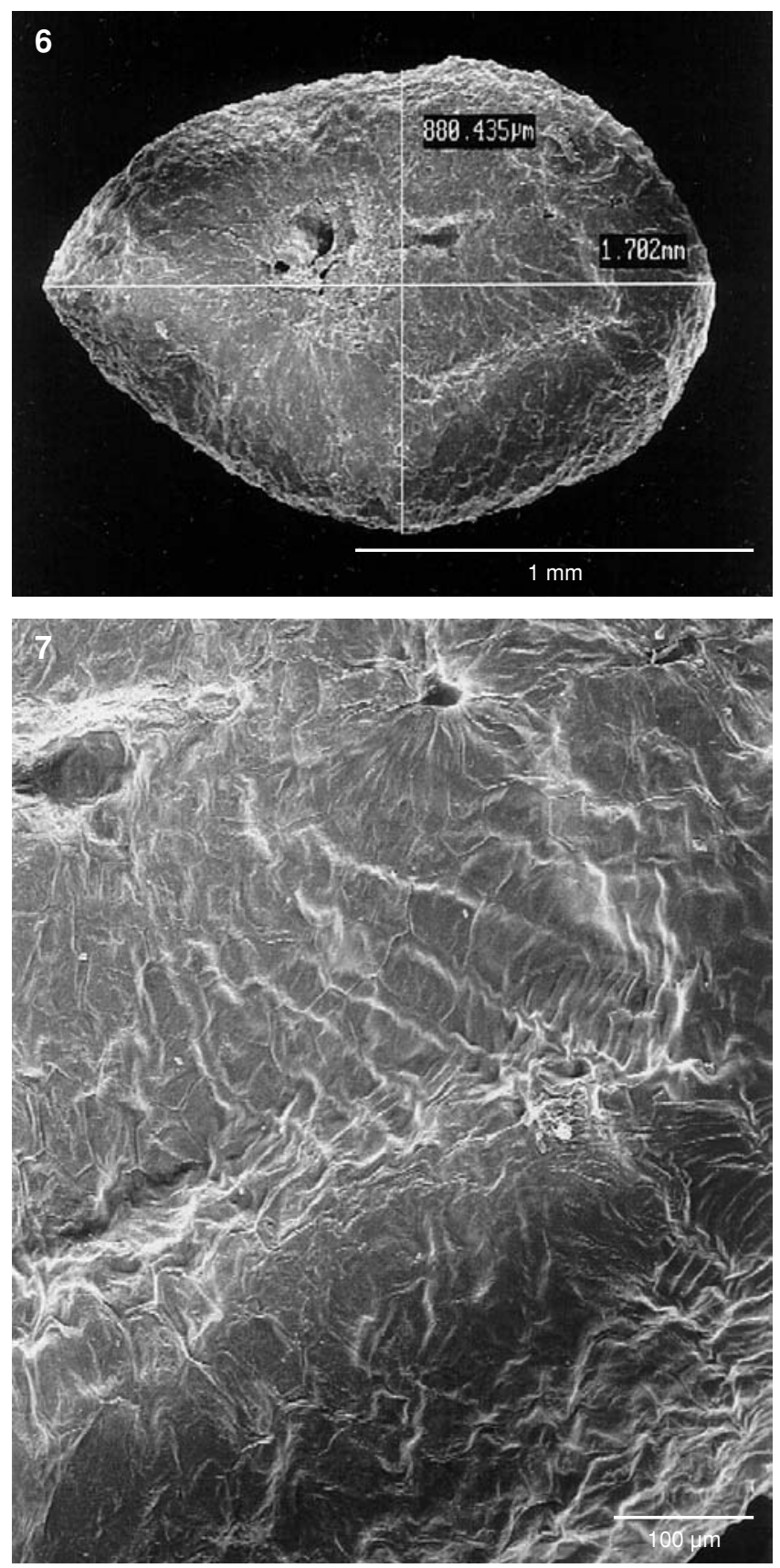

Figs 6, 7. Plantago intermedia Gilib. Fig. 6. (SEM) - Seed, ventral view, $(\times 46)$. Fig. 7. (SEM) - Seed sculpture on ventral side, $(\times 163)$.

\section{P. arenaria}

25. Wielkopolska, Puszczykówko, Puszczykowo Commune - sandy patch surrounded by forest.

26. Wielkopolska, Rogalinek, Mosina Commune - sandy patch surrounded by forest.

27. Wielkopolska, Skorzęcin, Witkowo Commune - sandy patch surrounded by forest.

28. Wielkopolska, Szreniawa, Komorniki Commune sandy patch surrounded by forest.

The sculpture of 30 seeds of each taxon was investigated under a light microscope. In addition, the surface of seeds were analysed using replicas prepared with the application of the cuticular technique (Klimko 1981) at magnifications 120x and 140x. Additionally, SEM observations were made in the Laboratory of Electron Microscopy - Adam Mic- kiewicz University, Poznań. The presented micrographs show the typical seed sculpture of each species, and the magnification is specified. Nomenclature follows that recommended by Mirek et al. (1995).

\section{RESULTS AND DISCUSSION}

The shape of seeds of Plantago species varies considerably: elliptic, peltate, angular, ovoid, convex on the dorsal side, flat or boat-like concave on the ventral side, with the hilum at the centre. Embryo central, somewhat flattened, orthotropous, only slightly shorter than the seed, with narrow cotyledons parallel or perpendicular to the long axis of the seed (see Figs 4, 19 and 24).

\section{SECTION Plantago L.}

\section{P. major L.}

Seed outline elliptic, nearly rhomboid or trapezoid. Dorsal side convex, rarely flattened (Fig. 2). Surface dull, light brown to dark olive-brown. Dorsal side of testa with a regular structure of cells arranged in tiers, with straight walls (Fig. 3). Ventral side \pm nearly flattened, with elliptic or circular hilum at the centre (Fig. 4). On ventral side, verrucose folds radiate from hilum to seed edge (Fig. 5). The dorsal seed surface is not slightly rugose, as reported by Szafer et al. (1968), Rymkiewicz (1979), and Rothmaler et al. (1982).

\section{$P$. intermedia Gilib.}

Seed shape variable and irregular, outline elliptic. Dorsal side convex. Surface dull, light brown to dark brown. Dorsal side of testa with an irregular, rugose sculpture, slightly verrucose. Ventral side slightly convex, hilum poorly defined (Fig. 6), Ventral side rugose, roof-like elevated towards hilum (Fig. 7), quite regularly radiate, as in $P$. major. Close to seed edge, testa slightly verrucose. The above description of sculpture is consistent with earlier published data (Tacik 1967; Rymkiewicz 1979).

\section{SECTION LAMPROSANTHA DECNE}

\section{P. media L.}

Seeds peltate, outline elliptic or ovoid. Dorsal side convex (Fig. 8). Surface dull, olive to dark brown or black. Sculpture reticulate, slightly verrucose and rugose (Fig. 9). Ventral side slightly boat-shaped, concave or flat, with a rough rounded hilum at the centre (Fig. 10). Sculpture around hilum reticulate, with large interstices, walls straight, longitudinal walls parallel to seed edge (Fig. 11). Seed tips rounded, often truncate horizontally or obliquely, sometimes with a white 'crest' at one end. Earlier the sculpture was described as slightly rugose (Kulpa 1988; Tacik 1967).

In this paper the former section Coronopus DC was divided into two sections: Coronopus sensu Rahn and Maritima Rahn. This is consistent with the classifications proposed by Rahn (1978) and Dietrich (1980). Such a classification is confirmed by earlier research on genetics (Cartier 

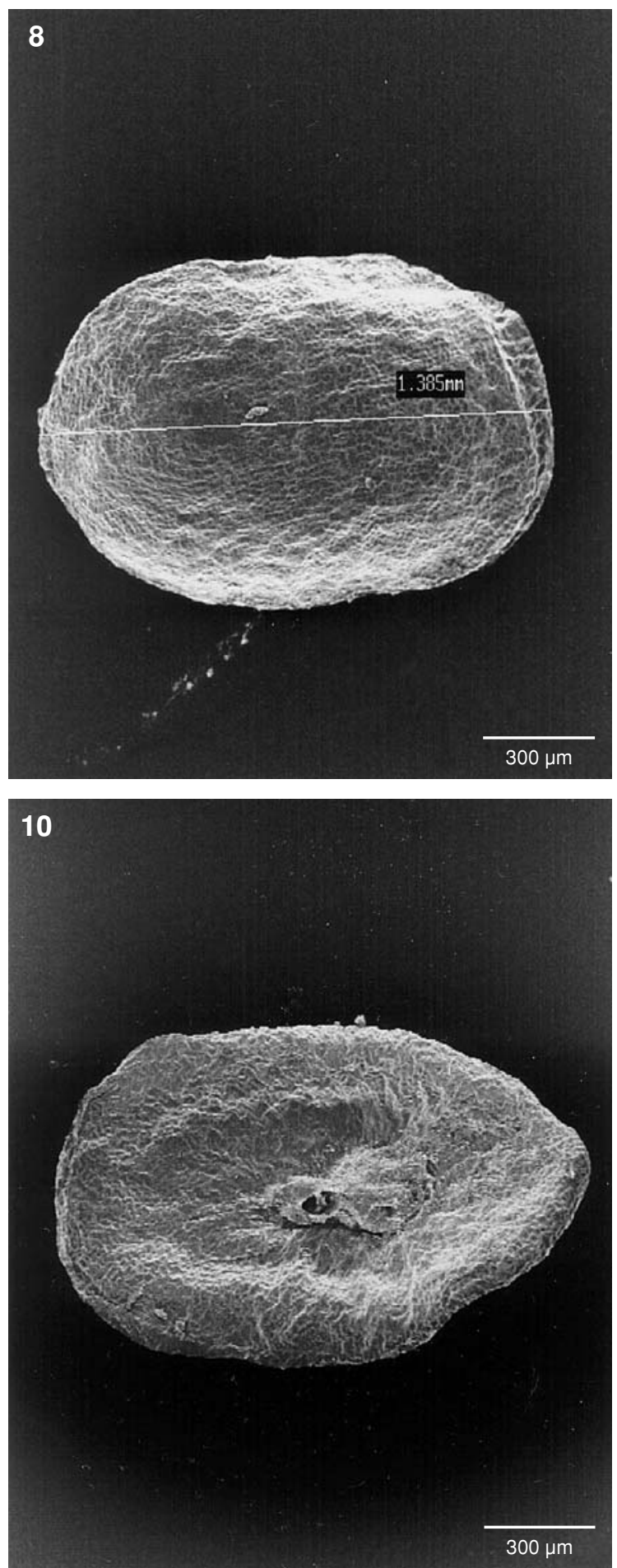
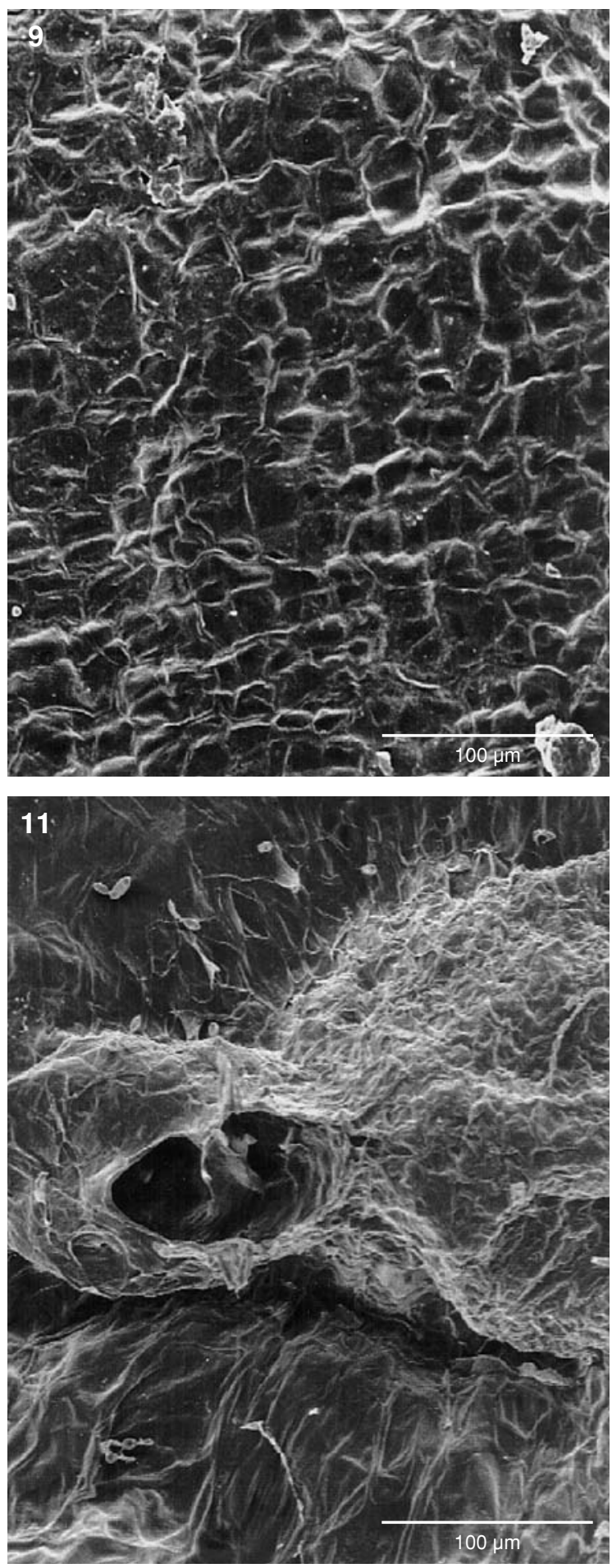

Figs 8-11. Plantago media L. Fig. 8. (SEM) - Seed, dorsal view, (×55). Fig. 9. (SEM) - Seed sculpture on dorsal side, $(\times 163)$. Fig. 10. (SEM) Seed, ventral view, $(\times 55)$. Fig. 11. $($ SEM $)-$ Seed sculpture on ventral side, $(\times 312)$.

1973), seed anatomy (Trapp 1932; Rymkiewicz 1979), cytology (Dietrich 1980), chemotaxonomy (Gorenflot, Bourdu 1962; Rymkiewicz 1978; Andrzejewska-Golec, Świątek 1984), palynology (Clarke, Jones 1977), and morphology (Andrzejewska-Golec, Świętosławski 1987; Rymkiewicz 1979). Plantago coronopus differs from $P$. maritima in the number of chromosomes $(\mathrm{x}=6)$, presence of ribose, lack of aucubin in seeds, and characteristic, bottle-shaped trichomes on leaves, bracts and scapes.

\section{SECTION CORONOPUS SENSU RAHN}

\section{P. coronopus L. subsp. coronopus}

Seeds ovoid or \pm elliptic in outline, with a characteristic beak. Dorsal side convex. Surface dull, olive to brown. Dorsal side also convex, with a well-defined hilum having regular edges (Fig. 12). Sculpture of dorsal and ventral side regularly reticulate (Fig. 13). Cells with undulated walls, filled with strips directed towards the centre, sometimes leaving an empty funnel at the centre. Seed surface with ornamentation 

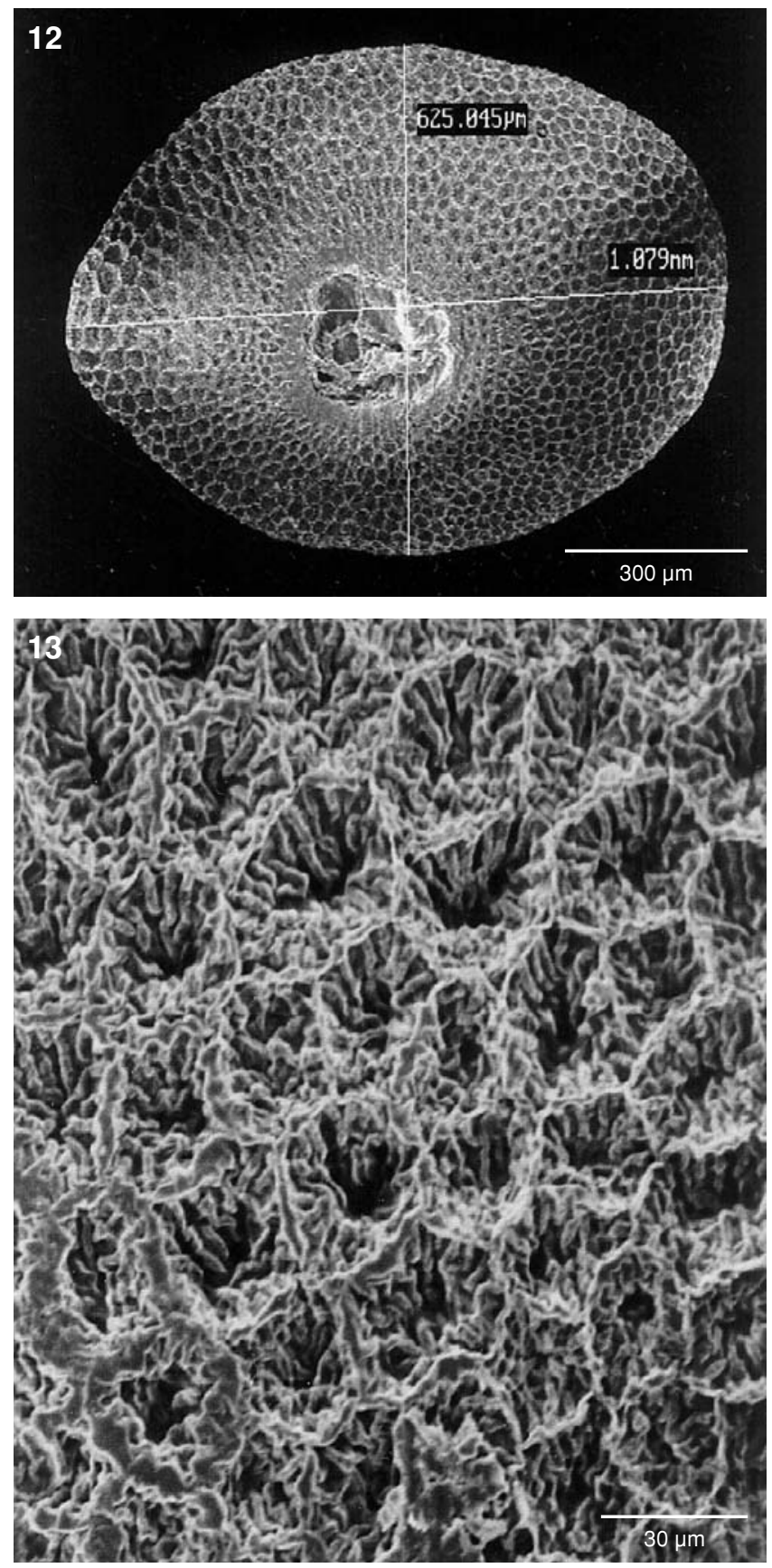

Figs 12, 13. Plantago coronopus L. subsp. coronopus. Fig. 12. (SEM) Seed, ventral view, $(\times 72)$. Fig. 13. (SEM) - Seed sculpture on ventral side, $(\times 573)$.

visible under a light microscope. The Polish sample was compared with a sample of 50 seeds collected in Poradge (Croatia) in 2002. No variation in seed sculpture was observed but the two samples differed in seed dimensions.

\section{SECTION MARITIMA RAHN}

\section{P. maritima L. subsp. maritima}

Seeds elliptic to ovoid. Dorsal side convex. Surface dull, brown to dark brown. Sculpture reticulate, with variable ornamentation: interstices completely filled with regularly arranged balls as well as strips like those in $P$. coronopus subsp. coronopus (Figs 15, 16). Ventral side flat, hilum located in the wider part of the seed (Fig. 14). Seeds of spe-
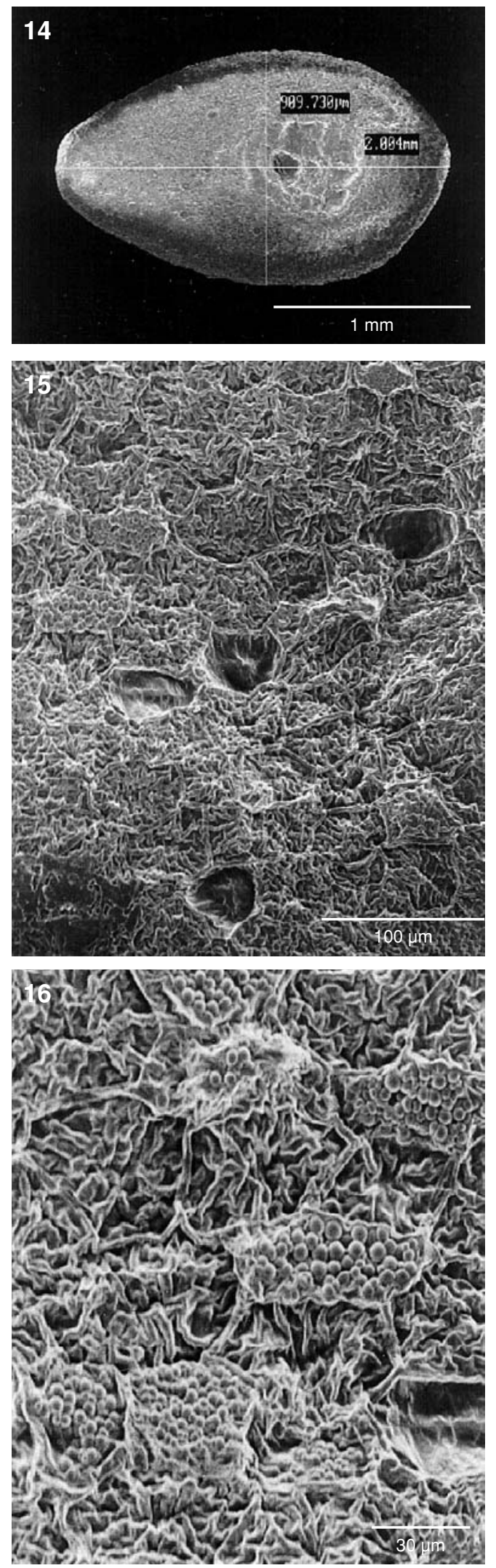

Figs 14-16. Plantago maritima L. subsp. maritima. Fig. 14. $(\mathrm{SEM})-$ Seed, ventral view, $(\times 37)$. Fig. 15. $($ SEM $)-$ Seed sculpture on dorsal side, $(\times 312)$. Fig. 16. $($ SEM $)-$ Seed sculpture on ventral side, $(\times 625)$

cies belonging to the sections Coronopus and Maritima are characterized by a varied ornamentation. Cotyledons perpendicular to the longitudinal axis of the seed. 

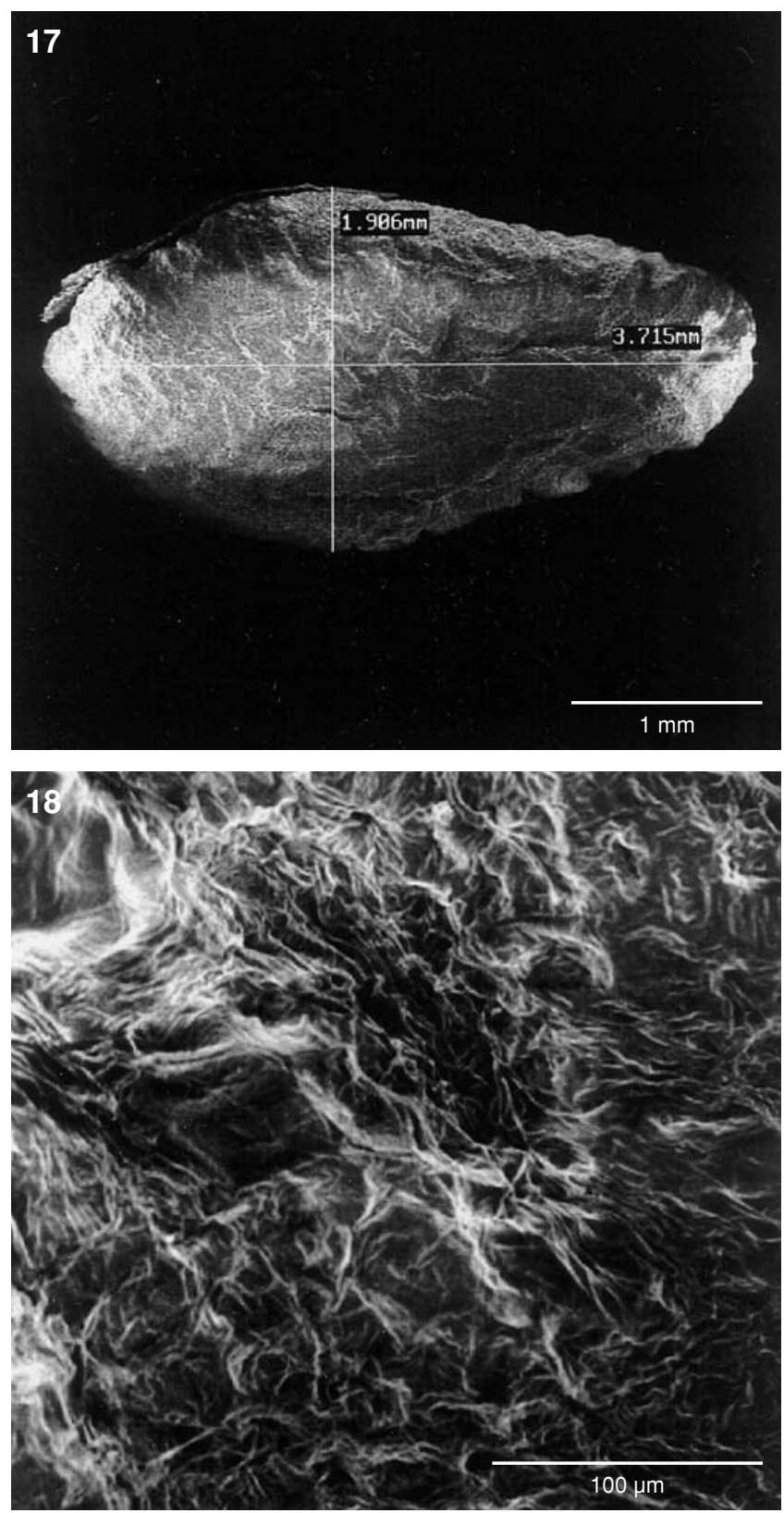

Figs 17, 18. Plantago atrata Hoppe subsp. carpatica (Soó) Soó. Fig. 17. (SEM) - Seed, dorsal view, (×27). Fig. 18. (SEM) - Seed sculpture on dorsal side, $(\times 312)$.

\section{SECTION OREADES DECNE}

\section{P. atrata Hoppe subsp. carpatica (Soó) Soó}

Seed outline elliptic. Dorsal side convex (Fig. 17). Surface brown to black. Both dorsal and ventral side deeply rugose, with a poorly differentiated sculpture; edges curved, rugose, smooth. On ventral side, deeper folds especially near hilum (Fig. 18). Seeds of $P$. atrata subsp. carpatica differ from those of all the other studied species in the deeply rugose sculpture of the whole surface.

\section{SECTION ARNOGLOTTIS T. TACIK}

\section{P. lanceolata $\mathrm{L}$.}

Seed outline narrowly elliptic or ovoid. Surface yellowish to dark brown. Dorsal side smooth, shiny, with a yel-
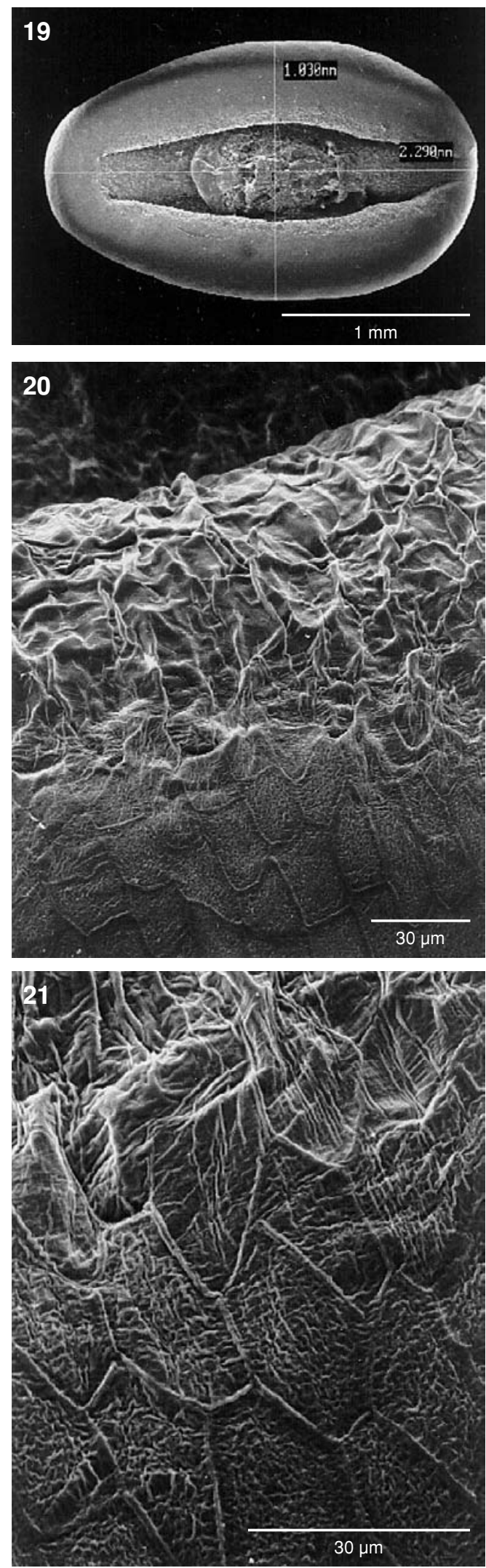

Figs 19-21. Plantago lanceolata L. Fig. 19. (SEM) - Seed, ventral view, $(\times 36)$. Fig. 20. (SEM) - Seed sculpture on ventral side, $(\times 625)$. Fig. 21. (SEM) - Seed sculpture on ventral side, $(\times 1420)$.

low longitudinal stripe. Ventral side boat-shaped, concave, dull (Fig. 19). Hilum oval, at the centre of the ventral side, surrounded with a belt of slightly undulated cells, slightly verrucose, so its sculpture is rough (Fig. 20). Sculpture of 

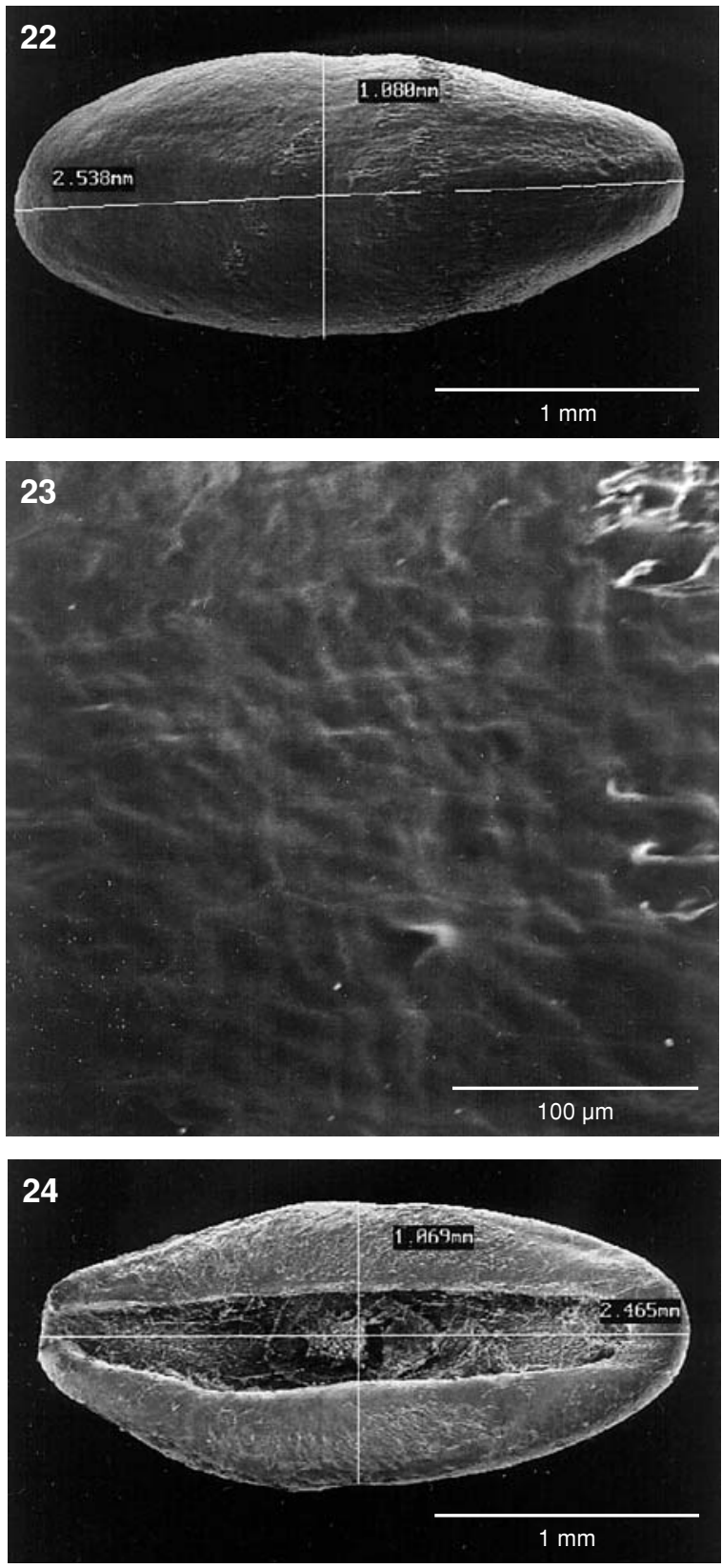

Figs 22-24. Plantago arenaria Waldst. and Kit. Fig. 22. (SEM) Seed, dorsal view, $(\times 33)$. Fig. 23. (SEM) - Seed sculpture on dorsal side, (×312). Fig. 24. (SEM) - Seed, ventral view, $(\times 33)$.

dorsal and ventral side (to hilum edge) reticulate, made of regular hexagonal cells with straight walls and internal minute ornamentation (Fig. 21).

\section{SECTION PSYLLIUM (JUSS.) BERNEOUd}

\section{$P$. arenaria Waldst. and Kit.}

Seeds boat-shaped, narrowly elliptic in outline. Similar to those of $P$. lanceolata. Surface dark brown, very shiny. Dorsal side convex, with a conspicuous light longitudinal stripe. The seed is narrowed at half the length, at the same level as the embryo (Fig. 22). Ventral side boat-shaped, edges curved to the ventral side, usually flattened longitudinally (Fig. 24). Dorsal and ventral sculpture to edges rugose, slightly verrucose (Fig. 23).

\section{CONCLUSIONS}

1. Clear interspecific differences were found on the basis of observations of seed sculpture under a light and scanning electron microscope.

2. Seeds of species of the section Plantago (P. major and $P$. intermedia) show variation in dorsal sculpture. In $P$. $m a-$ jor epidermal cells are regularly arranged in tiers, while in $P$. intermedia, the sculpture is irregular, rugose, slightly verrucose. Ventral sculpture rugose, and the folds radiate from the hilum quite regularly.

3. Seeds of $P$. coronopus subsp coronopus (section Coronopus) and $P$. maritima subsp. maritima (section Maritima) are characterized with specific ornamentation. In the sculpture of $P$. coronopus subsp. coronopus and $P$. maritima subsp. maritima, cells have undulate walls, filled with strips directed towards the centre, whereas in $P$. maritima subsp. maritima additionally the interstices in reticulate sculpture are completely filled with regularly arranged balls. Moreover, seeds of $P$. coronopus subsp. coronopus have characteristic beaks.

4. The results of this study show that seeds of $P$. atrata subsp. carpatica has a poorly differentiated sculpture, as the whole surface is rugose.

5. Seeds of $P$. lanceolata and $P$. arenaria are characterized with the presence of a light longitudinal stripe. The two species differ in seed sculpture. The surface of $P$. lanceolata seeds is regularly reticulate; the pattern is formed by elongated, polygonal cells with internal ornamentation. In $P$. arenaria the sculpture is slightly rugose.

\section{LITERATURE CITED}

ANDRZEJEWSKA-GOLEC E. 1997. Taxonomic aspects of the iridoid glucosides occurring in the genus Plantago L. Acta Soc. Bot. Pol. 66 (2): 201-205.

ANDRZEJEWSKA-GOLEC E., OFTERDINGER DAEGEL S., CALIS I., ŚWIĄTEK L. 1993. Chemotaxonomic aspects of iridoids occurring in Plantago subg. Psyllium (Plantaginaceae). Pl. Syst. Evol. 185: 85-89.

ANDRZEJEWSKA-GOLEC E., ŚWIĄTEK L. 1984. Badania chemataksonomiczne rodzaju Plantago. I Analiza frakcji irydoidów. Herba Polon. 30: 9-16.

ANDRZEJEWSKA-GOLEC E., ŚWIĘTOSŁAWSKI J. 1987. The morphology of hairs in species of Plantago L. sectio Coronopus DC. Acta Soc. Bot. Pol. 56: 367-379.

ANDRZEJEWSKA-GOLEC E., ŚWIĘTOSŁAWSKI J. 1989a. The morphology of hairs in taxa of the genus Plantago L. Sectio Oreades Decne. Acta Soc. Bot. Pol. 58: 549-561.

ANDRZEJEWSKA-GOLEC E., ŚWIETOSŁAWSKI J. 1989b. The morphology of hairs in species of Plantago L. Sections Bamphula Decne and Arnoglossum Decne. Acta Soc. Bot. Pol. 58: $15-45$.

BORKOWSKI B. 1957. Farmakognozja z uwzględnieniem fitochemii i farmakodynamiki surowców roślinnych. PZWL, Warszawa.

CARTIER D. 1973. Etude biosystématique de quelques espéces du genre Plantago (Tourn) L. (section Coronopus DC.) III. Apports de croisements expérimentaux chez les $P$. alpina L. et $P$. serpentina All. Conclusions sur le complexe P. alpina $-P$. serpentina. Rev. Gén. Bot. 80: 5-40.

CASPER J. 1974. 121. Familie Plantaginaceae, In: Hartl D., et Wagenitz G., (ed.), Hegi G., Illustrierte Flora von Mitteleuropa, ed. 2, 6/1: 559-608, Berlin et Hamburg. 
CHATER A.O., CARTIER D. 1976. Plantago L. In: Flora Europaea. Tutin T.G., Heywood V.H., Burges N.A., Moore D.M., Valentine D.H., Walters S.M., Welb D.A. (eds) Cambridge Univ. Press, Cambridge, Vol. 4, pp. 38-44.

CHRTEK J. Jr. 2000. Plantaginaceae. [in] Kvetna Ćeskě Republiky. B. Slavik (ed), Academia, Praha, 6: 529-547.

CLAPHAM A.R., TUTIN T.G., WARBURG E.F. 1962. Flora of the British Isles. Cambridge University Press, pp. 764-764.

CLARKE G.C.S., JONES M.R. 1977. The Northwest European Pollen Flora 15, Plantaginaceae. Rev. Paleobot. Palynol. 24 (4): 129-154.

DIETRICH H. 1980. Cytologische Untersuchung innerhalb der Familie der Plantaginaceae. III. Cytotaxonomische Ergebnise. Wiss. Ztschr. Friedrich - Schiller Univ. Jena, Math. - Naturwiss. 29: 559-587.

DUSINSKY G., TYLLOVA M. 1960. Der Gehalt von Aukubin in einigen unseren Wedericharten (Plantago L.) und in galenischen Preparaten. Ceskoslov. Farm. 9: 60-62.

GARCKE A. 1972. Illustrierte Flora Deutschland und angrenzende Gebiete. Verl. Paul Parey, Berlin und Hamburg, 23: 1340$-1344$.

GORENFLOT R., BOURDU R. 1962. Criteries biochimiques et taxonomie expérimentale du genere Plantago. Rev. Cytol. Biol. Vég. 25: 349-360.

HANDJIEVA N., SAADI H., EVSTATIEVA L. 1991. Iridoid glucosides from Plantago altissima L., Plantago lanceolata L., Plantago atrata Hoppe and Plantago argentea Chaix. Z. Naturforsch 46: 993-965.

KLIMKO M. 1981. Zmienność populacji i stanowisko systematyczne Carex nigra (L.) Reich. w Polsce. PWN, Warszawa-Poznań. (in Polish with English summary)

KULPA W. 1988. Nasionoznastwo chwastów. PWRiL, Warszawa, pp. 258-262. (in Polish)

MEUSEL H., JÄGER E., RAUSCHERT S., WEINERT E. 1978. Vergleichende der Chorologie Zentraleuropaischen Flora. Bd. II. G. Fischer vest., Jena, pp. 415-417.

MIREK Z., PIĘKOŚ-MIRKOWA H., ZAJĄC A., ZAJĄC M. 1995. Krytyczna lista roślin naczyniowych Polski. A check list [Vascular plants of Poland]. Pol. Bot. Stud. Guicleb., Ser. 15. (in Polish)

PIEKOŚ-MIRKOWA H. 2001. Plantago atrata Hoppe. [In:] Polska Czerwona Księga Roślin. Kaźmierczakowa R., Zarzycki K. (eds). PAN Kraków, pp. 349-350. (in Polish with English summary)

PILGER R. 1937. Plantaginaceae. In: Das Pflanzenreich. Engler A., Diels L. (eds), Verlag von Wilhelm Engelmann Leipzig. Vol. 4, pp. 1-466 (Monograf.).

PIOTROWSKA H. 2001a. Plantago coronopus L. babka pierzasta. [In:] Polska Czerwona Księga Roślin. Kaźmierczakowa R., Zarzycki K. (eds). PAN Kraków, pp. 345-346. (in Polish with English summary)
PIOTROWSKA H. 2001b. Plantago maritima L. babka nadmorska. [In:] Polska Czerwona Księga Roślin. Kaźmierczakowa R., Zarzycki K. (eds). PAN Kraków, pp. 347-348. (in Polish with English summary)

PIOTROWSKA H., ŻUKOWSKI W, JACKOWIAK B. 1997. Rośliny naczyniowe Słowińskiego Parku Narodowego. [Vascular plants of the Słowiński National Park.] Prace Zakł. Taksonomii Roślin Uniw. A. Mickiewicza, Bogucki Wydaw. Nauk., Poznań. (in Polish with English summary)

RAHN K. 1978. Nomenclatorial changes within the genus Plantago L., intraspecific taxa and subdivisions of the genus. Bot. Tidsskrift, 73: 106-111.

RAHN K. 1996. A phylogenetic study of the Plantaginaceae. Bot. J. Linn. Soc., 120: 145-198.

RASZEJA W., GILL S. 1973. Zawartość aukubiny w nasionach rodzaju Plantago L. Rozpr. Wydz. III Nauk Mat. Przyr., 9: 155-199. (in Polish with English summary)

ROTHMALER W., MEUSEL H., SCHUBERT R. 1982. Exkursionsflora für die Gebiete der DDR und der BRD. Voll und Vissen Volkseigener Verlag, Berlin, pp. 387-388.

RUTKOWSKI L. 1998. Klucz do oznaczania roślin naczyniowych Polski niżowej. PWN, Warszawa. (in Polish)

RYMKIEWICZ A. 1979. Badania nad gatunkami z rodzaju Plantago L. z uwzględnieniem karpologii i chemotaksonomii Studies on the species of the genus Plantago L. with reference to carpology and chemotaxonomy. Monogr. Bot., 57: 71-103. (in Polish with English summary)

SAADI H., HANDJIEVA N.N., POPOV S., EVSTATIEVA L. 1990. Iridoids from Plantago media. Phytochemistry, 29: 3938-3939.

SWABRICK J.T., RAYMOND J.C. 1970. The identification of the seeds and achenes of British Plantaginaceae. Ann. Bot. 34 (138): 1123-1129.

SZAFER W., KULCZYŃSKI S., PAWŁOWSKI B. 1969. Rośliny polskie. PWN, Warszawa, 594-596. (in Polish)

ŚWIĄTEK L., LEHMANN D., CHAUDHURI R.K. STICHER O. 1981. Occurrence of meittoside in the seeds of Plantago media. Phytochemistry 20: 2023-2024.

TACIK T. 1967. Rodzina Plantaginaceae - Babkowate. [In:] Flora Polska. Rośliny naczyniowe Polski i ziem ościennych. B. Pawłowski [ed]. PWN, Warszawa, Kraków, 11: 238-256. (in Polish)

TRAPP G. 1932. A study of the foliar endodermis in the Plantaginaceae. Trans. Roy. Soc. Edin. 57: 523-546.

VODÁK A. 1956. Semena nebo plody našich kulturních rostlin a nejčastějsích plevelů. Československá Akademie Zemědělských Věd ve Státním Zemědělskěm Nakladatelství, Praha pp.: 58-59. (in Czech with English summary)

ZAJĄC A., ZAJĄC M. 2001. Atlas rozmieszczenia roślin naczyniowych w Polsce. Distribution Atlas of Vascular Plants in Poland. (in Polish with English summary) 